\title{
CONFLICT BETWEEN EXPLICIT AND TACIT PUBLIC SERVICE BARGAINS IN UK EXECUTIVE AGENCIES
}

Article forthcoming in Governance: An International Journal of Policy, Administration and Institutions

Dr Thomas Elston, ${ }^{\mathrm{i}}$

Blavatnik School of Government, University of Oxford

\begin{abstract}
Public service bargains (PSBs) define rewards, competencies and loyalties for civil servants. They involve both explicit and tacit agreements with politicians. The article suggests that these two kinds of bargain may not be closely coordinated with one another, and can become "loosely coupled", operating and evolving with relative independence. This is particularly likely when there is conflict between rational-actor preferences and institutional expectations about political-administrative behavior. Such a trade-off can be managed by "decoupling" the explicit and tacit PSB, so that they operate differently in public and in private. Loose coupling results in inconsistent PSBs that are resistant to change, whereas decoupling highlights the compliance costs that actors face when securing cultural legitimacy for their bargains. These arguments are illustrated by the long-term development of 'Next Steps' agencies in the U.K., where a marked disjuncture has emerged between the stated and practiced PSB.
\end{abstract}

\section{Keywords}

Blame games, civil service reform, decoupling, delegation, institutional theory

\section{Suggested citation}

Elston, T. (forthcoming, 2016). "Conflict between explicit and tacit public service bargains in UK executive agencies." Governance.

\footnotetext{
${ }^{i}$ thomas.elston@bsg.ox.ac.uk |(+44)(0)1865 614377

The Blavatnik School of Government, Radcliffe Observatory Quarter, Oxford OX2 6GG
} 


\section{CONFLICT BETWEEN EXPLICIT AND TACIT PUBLIC SERVICE BARGAINS IN UK EXECUTIVE AGENCIES}

\section{INTRODUCTION}

Public service bargains are the terms of engagement between government bureaucrats and those whom they serve - especially elite politicians, but also legislatures and the citizenry (Hood \& Lodge, 2006). They are correlative agreements about roles, rights and responsibilities, driven by interdependence in each party's utility function. Thus, politicians might look for expertise, loyalty or neutrality from their bureaucrats, hoping to enhance policy success and political reputation. But these rely upon civil service cooperation. Bureaucrats may value permanence, anonymity or policy influence, but these require political sanction. Although the manner and strength of this interdependence varies between contexts, it results in patterns of dealmaking that are widespread (Hood \& Lodge, 2006). This makes public service bargains (hereinafter PSBs) a useful basis for longitudinal and cross-national comparisons of civil service systems and public management reforms (Salomonsen $\&$ Knudsen, 2011; Burns et al., 2013; Van der Meer et al., 2013).

PSBs consist of both explicit and implicit agreements, "expressed in convention or formal law or a mixture of both" (Hood, 2001, p.12). This duality means that actors need not converse openly with one another in reaching an accord (see Schelling, 1956). It also means that informal codes of behavior remain important, despite processes of contractualization in many governments (Lægreid, 2000). But, aside from these two basic corollaries, is there any further significance to the combination of explicit and tacit deal-making? This question has received little attention to date, with empirical research mainly focused on classifying PSBs and tracing their reform. Yet this article contends that concurrent explicit and tacit bargaining is significant for at least two additional and interrelated reasons.

The first is that, given their rival characteristics, composite PSBs involve two very different types of agreement that might not be closely coordinated. Explicit PSBs determine basic employment conditions, are made in view of the public, and are modified only periodically. Unwritten or 'tacit' bargains, conversely, often decide non-standard items of utility, are more readily modified, and - crucially - are less visible to non-participant observers. Given these differences, composite PSBs might become "loosely coupled" (Weick, 1976), with semi-independent explicit and tacit 
deals moving in and out of alignment. This complicates the overall PSB and creates built-in change resistance.

The second, related significance of the explicit-tacit duality is its potential to satisfy multiple criteria for successful political-administrative relations. PSBs derive from strategizing by utility-maximizing actors, and thus partly reflect their preferences and compromises; but, in order to gain wider legitimacy, PSBs must also adhere to cultural beliefs about appropriate political organization. If tensions or tradeoffs should arise between these rational-actor and cultural-institutional logics, the differing visibility of explicit and tacit bargains to external legitimacy-defining constituencies (like core executives, legislatures, and citizens) allows bargaining actors to "decouple" the frontstage and backstage deal, and satisfy competing imperatives by operating differently in public and in private (Meyer \& Rowan, 1977; Brunsson, 2002).

The article develops these two arguments as follows. It begins by describing PSBs in more detail. It then explores differences between explicit and tacit bargains and how discrepancies might emerge between the two, particularly through rationalinstitutional conflict. Next comes a detailed example: the long-term evolution of 'Next Steps' agencies in the U.K. justice policy sector. Based on more than fifty interviews and extensive documentary analysis, this case demonstrates how explicit and tacit PSBs can detach from one another and operate differently at the frontstage and backstage of a political bureaucracy. The conclusion describes the implications of loose coupling and decoupling for future PSB research and for policymakers looking to reform the conditions of public service.

\section{PUBLIC SERVICE BARGAINS}

Relations between politicians and bureaucrats are an enduring interest in political science (Aberbach et al., 1981), and the idea that these actors negotiate their terms of engagement dates back at least to Bernard Schaffer's (1973, pp.250-263) work on nineteenth-century British government. More recently, Christopher Hood and Martin Lodge developed the concept of public service bargains, demonstrating its international relevance and proposing a multileveled taxonomy (Hood, 2001, 2002; Hood \& Lodge, 2006). This section explores the theoretical assumptions behind PSBs, their main dimensions and classifications, and existing empirical research. 


\section{Cooperation, interdependence and bargaining}

Theoretically, the PSB concept can be reasoned in three stages. First is Chester Barnard's (1938) classic work on the inducement-contribution balance (see also March \& Simon, 1993). Barnard viewed organizations as systems of cooperating individuals, where each member has a potential contribution of value to the enterprise, such as physical exertion, skills or knowledge. To elicit these contributions, organizations provide members with inducements, both pecuniary and otherwise. Doing so is costly, and so leaders must strike a balance: "The equilibrium of the organization economy requires that it shall command and exchange sufficient of the utilities of various kinds so that it is able in turn to command and exchange the personal services of which it is constituted" (Barnard, 1938, p.244).

The second step is to consider the unique 'economy' of inducements and contributions in a political bureaucracy. The utility functions of politicians and bureaucrats are interdependent. One group's inducement (the politician's desire for policy success, the bureaucrat's want of influence) requires the other's contribution (the bureaucrat's expertise, the politician's receptivity to advice). This creates what social-exchange theorists call reciprocal power-dependence, where "each party is in a position, to some degree, to grant or deny, facilitate or hinder, the other's gratification" (Emerson, 1962, p.32).

The corollary of this interdependence is that each party grants the other some form of inducement in order to be gratified themself. This is costly, and so parties bargain with one another, seeking to optimize their receipt of inducements and minimize their gift of contributions.

\section{Rewards, competencies and loyalties}

How do inducements and contributions, interdependence and bargaining explain civil service systems? According to Hood and Lodge, they manifest in the three dimensions of rewards, competencies and loyalties, which together form PSBs. Rewards are the package of inducements that secure bureaucratic participation. They include monetary and non-monetary elements, such as pay, pensions, job and career security, policy influence, prestige and honours. Exchanged for these rewards are competencies, which specify "what public servants are expected to know or do" (2006, p.22). Lastly is the loyalty and responsibility dimension, which includes both inducements and contributions. This defines "what public servants obtain from the 
bargain in the way of trust, responsibility or autonomy, and what they give up in terms of personal freedom or ability to 'play the field' politically" (2006, p.110). Loyalty thus describes the relationship between ministers and officials. This third dimension is the empirical focus below.

\section{Classifying PSBs}

Despite their variety, PSBs are patterned. Broadly, they divide between trustee-type bargains, which endow bureaucrats with authority direct from the citizenry or constitution, independent of elected politicians, and the more familiar agency-type bargain, where officials are subordinate to, and act on behalf of, ministers, who ultimately remain liable for the activity (Hood \& Lodge, 2006). There are then various subcategories (see Figure 1). Of particular relevance are the directed and the delegated types of agency bargain. Under the former, officials accept close political oversight, in return for anonymity and permanence. Conversely, for the delegated type (also known as the 'managerialist' bargain, reflecting its prevalence under new public management), officials enjoy more latitude in operational decisionmaking, are rewarded for high performance, and share liability for mishaps.

Figure 1: Types of PSB

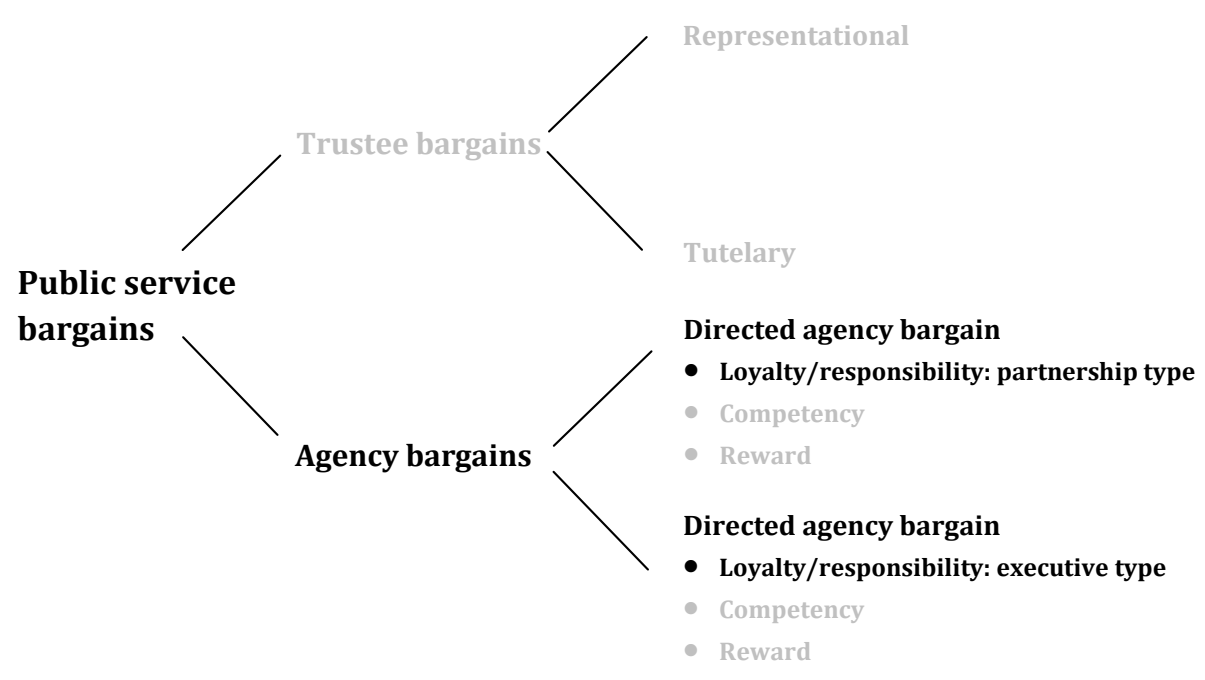

(Derived from Hood and Lodge (2006))

Different kinds of reward, competency and loyalty coalesce under the main PSB categories. Loyalty/responsibility bargains include a partnership type, where political-administrative relations are collaborative and there is no public bureaucratic identity independent of politicians. This aligns with the directed agency-type bargain. 
Conversely, with executive loyalty, officials remain ministerial agents, but have some distinct public identity and varying degrees of managerial independence to deliver prescribed policies and performance targets, following the delegated PSB (Hood \& Lodge, 2006).

\section{Empirical research}

Beyond the foundation supplied by Hood and Lodge, these ideas have received fairly limited testing. ${ }^{\text {ii }}$ Ideal-type PSB categories have been found rare in practice, with overlap and hybridization common (Steen \& Van der Meer, 2011; Bourgault \& Van Dorpe, 2013). The terms of PSBs can also be ambiguous, which can be used strategically by bargaining actors (Burns, et al., 2013). But ambiguity diminishes when PSBs are formalized in contracts or legislation (Salomonsen \& Knudsen, 2011; Van der Meer, et al., 2013). Finally, there is some evidence that stated and practiced PSBs can be inconsistent. In Belgium, Annie Hondeghem and Karolien Van Dorpe (2013, p.22) found a "strong managerial PSB on paper" was weaker "in practice," while, in the Netherlands, Trui Steen and Frits Van der Meer (2011, p.229) observed a "disconnection between aspirations and practice." This highlights the need to consider more fully the causes and consequences of incongruence in PSBs.

There are also limitations in existing research. Studies generally focus on classification, without connecting this to interdependence, strategic behavior and 'cheating' (where actors renege on their agreement), or to more basic public administration problems, like accountability and control. Without exposing the mutual conditionality upon which bargains depend or using PSBs to explore wider concerns of the discipline, it might be questioned how compelling the PSB approach is. In addition, studies mostly examine cross-governmental bargains without considering particular organizations or variation across policy sectors or organizational types (but see Lodge, 2010). And the focus is often on extraordinary moments of political-administrative bargaining, such as legislative change or administrative reform, rather than day-to-day deals.

\footnotetext{
ii See symposia in Public Policy and Administration (Vol. 26, No. 2) and International Review of Administrative Sciences (Vol. 79, No.1).
} 


\section{LOOSELY COUPLED AND DECOUPLED PSBs}

\section{Explicit and tacit bargains}

Various terms have been used to describe the epistemological dualism with which this article is concerned, including 'explicit-tacit', 'formal-informal', 'writtenunwritten', and 'law-convention'. Each indicates that the PSB extends beyond its prima-face representation. In other words, the deal is "constituted by formal and informal components" (Bezes \& Lodge, 2015, p.143), so that, "regardless of the degree of formalization, there is always a highly ... informal aspect of bargains" (Salomonsen \& Knudsen, 2011, p.1020).

Explicit bargaining is apparent in many administrative reforms enacted since the 1980s, including the adoption of short-term employment contracts for senior civil servants (Lægreid, 2000); moves toward performance-based pay (Perry et al., 2009); the development of 'competency frameworks' to guide recruitment and training (Hood \& Lodge, 2006, p.88); and the growth of professional codes regulating matters such as impartiality (Grube, 2015). Each testifies to an increase in PSB codification (Lodge, 2010). But what makes a bargain explicit rather than tacit? At the risk of simplification, it is useful to compare five bargaining characteristics: subject, process, timing, product and visibility.

Regarding subject, explicit PSBs mostly determine core elements of Barnard's inducement-contribution equilibrium, like remuneration and qualifications. More subtle perks or requirements are left implicit (see below). The deal-making process is also forward-looking, determining ex-ante conditions for bonus payments or official criteria for adjudicating impartiality; and negotiations are deliberate, articulate and sometimes even high-profile and staged. The timing of explicit bargaining is thus fairly concentrated and controlled, and precedes the deal's implementation. The product of the negotiations is generally recorded in legislation, regulations or (quasi)contracts; and even if not, the deal is 'explicit knowledge', meaning that actors acknowledge it, articulate it and can easily communicate it (Polanyi, 1958). Explicit PSBs are therefore visible to outside observers, as when ministers announce management reforms to legislatures and headhunters advertise desired competencies.

By comparison, tacit PSBs are more indeterminate. As Sidney Low (1904, p.12) remarked of British government, "We live under a system of tacit understandings. But the understandings themselves are not always understood." Historically, implicitly-agreed rewards included the relaxing of import duties for 
retiring U.K. diplomats returning from overseas (Hood \& Lodge, 2006, p.63). More broadly, Westminster-style civil service anonymity "emerged through practice and convention over time," rather than by design (Grube, 2015, p.5). And, in terms of loyalty, there is a growing informal expectation that officials speaking in public will not simply explain government policy but actively enthuse about it (Aucoin, 2012, p.189). As Peter Aucoin continues, "nowhere [is this] articulated as the norm for the public service. Everywhere, impartiality remains the official doctrine. ... Yet, breaches are commonplace."

Tacit bargaining subjects are thus more ancillary to the organizational equilibrium, specifying the unique perks of overseas service or the precise meaning of loyalty. Such bargains might also determine matters that are social taboos, as with the relaxing of tax laws for diplomats. Unlike the commotion surrounding some explicit deal-making, the tacit bargaining process is veiled and unacknowledged, albeit no less purposeful. As Thomas Schelling (1956, p.281) writes: "adversaries watch and interpret each other's behavior, each aware that his own actions are being interpreted and anticipated, each acting with a view to the expectations that he creates." Unspoken deals might thus arise in quite ordinary situations, as the need arises rather than ex ante. Their timing is less regulated and more diffuse, and the product comprises a series of implicit undertakings. This 'tacit knowledge' is difficult to articulate, record and share (Polanyi, 1958), meaning that such PSBs are understood through personal experience and are less visible to non-participants like citizens.

Table 1: Explicit and tacit bargains

\begin{tabular}{|l|l|l|}
\hline & \multicolumn{1}{|c|}{ Explicit PSBs } & \multicolumn{1}{c|}{ Tacit PSBs } \\
\hline Subject & Core inducements and contributions & $\begin{array}{l}\text { Extra inducements and contributions } \\
\text { Taboos }\end{array}$ \\
\hline Process & $\begin{array}{l}\text { Conscious, deliberate } \\
\text { Acknowledged, articulate } \\
\text { Staged, forward-looking }\end{array}$ & $\begin{array}{l}\text { Conscious, deliberate } \\
\text { Unacknowledged, inarticulate } \\
\text { Ad hoc, in-the-moment }\end{array}$ \\
\hline Timing & $\begin{array}{l}\text { Concentrated, discrete } \\
\text { Controlled }\end{array}$ & $\begin{array}{l}\text { Diffuse } \\
\text { Uncontrolled }\end{array}$ \\
\hline Product & Explicit knowledge & Tacit knowledge \\
\hline Visibility & $\begin{array}{l}\text { Visible to observers } \\
\text { Frontstage }\end{array}$ & $\begin{array}{l}\text { Less visible to observers } \\
\text { Backstage }\end{array}$ \\
\hline
\end{tabular}

This comparison of explicit and tacit PSBs is summarized in Table 1.

Significant differences are apparent in four of the five characteristics; and while both types have conscious and deliberate processes, the staged and forward-looking nature 
of explicit bargains also differs from in-the-moment tacit agreements. Consequently, Table 1 describes two systems of deal-making that operate quite differently and independently. Tacit understandings might inform explicit regulations, and formal policies might influence tacit knowledge. But neither is fully - or even closely determined by the other. Impartiality is a case in point. As noted, amid strengthened regulation of partisan conduct by bureaucrats, there is a growing tacit expectation that officials will proactively support government policies in public (Aucoin, 2012; Grube, 2015). Similarly, while modern competency frameworks emphasize private-sector qualities of management and leadership, political abilities remain an implicit qualification for civil servants (Hood \& Lodge, 2006, p.107). In both cases, the explicit and the tacit are inconsistent.

\section{Loosely coupled PSBs}

Organizational sociology offers the "loosely coupled organization" as a framework for conceptualizing explicit and tacit PSBs as related but independent agreements (Glassman, 1973; Weick, 1976; Orton \& Weick, 1990). As a critique of functionalism, which presupposed "an excess of unity, integration, coordination, and consensus" within organizations, loose coupling indicates that organizational components are "somehow attached" to one another, yet retain "some identity and separateness and ... their attachment may be circumscribed, infrequent, weak in its mutual affects, unimportant, and/or slow to respond" (Weick, 1976, pp.3-4). Many features of organizations can be loosely coupled, from teams and departments to authority structures and decisions (Orton \& Weick, 1990). Indeed, the influential 'garbage-can' model of decision-making posits loose coupling between problems and solutions (Cohen et al., 1976). Research has examined the conditions for, and consequences of, loose coupling, particularly in terms of buffering organizations from environmental change (Orton \& Weick, 1990). As Robert Glassman (1973, p.84) explains: "A system whose parts are less richly interconnected ... forms local stabilities which ignore limited perturbations elsewhere in the system."

Viewing PSBs as loosely coupled agreements has several implications. First, this strand of organizational sociology supports the idea that political-administrative deals need not be unified and may contain inconsistencies. Loose coupling developed to combine "the contradictory concepts of connection and autonomy" widely observed of organizations (Orton \& Weick, 1990, p.216). Second, loose coupling 
indicates new avenues for PSB research concerning when explicit-tacit misalignment occurs and what its consequences are for bargain participants and observers. For instance, inertial properties might mean explicit deals are delayed and/or diluted in practice. This could explain the policy-practice disconnect noted in previous PSB research (Steen \& Van der Meer, 2011; Hondeghem \& Van Dorpe, 2013). As for causality, the different characteristics of explicit and tacit bargains (Table 1) indicate several pathways to incongruence. The variety of subjects agreed within a PSB, and their uneven distribution between the explicit and tacit terms, might produce discrepancies. Similarly, differences of timing could produce gaps between up-todate and out-of-date PSBs. And, from a cultural perspective, the greater external visibility of explicit bargains creates what Erving Goffman (1956) calls a separate "frontstage" and "backstage." This is elaborated below.

\section{Decoupled PSBs - An institutional account}

One of the most developed applications of loose coupling comes in institutional theory, which considers decoupling as a response to regulative, normative and cognitive pressures for organizations to reflect wider values and beliefs in society (Scott, 1995). Organizations require cultural legitimacy to secure resources from the environment, and this derives not only from the quality of organizational outputs (which may be indeterminable), but also from their manner of production (Brunsson, 2002; Boxenbaum \& Jonsson, 2008). Consequently, organizations abide by "theories of production that are ingrained in the public imagination and legitimated by the educational system, the legal and political system, and professional bodies" (Bromley \& Powell, 2012, p.487). However, problems arise when these generic management scripts bring adoption costs. There may be trade-offs with productive efficiency, since "to coordinate and control activity in order to promote efficiency [often] undermines an organization's ceremonial conformity” (Meyer \& Rowan, 1977, pp.340-341). Heterogeneous environments might produce inconsistent demands, making compliance complex and costly (Brunsson, 2002). And institutional obedience may levy personal costs upon organizational leaders, like reducing financial rewards (Westphal \& Zajac, 2001) or ideological preferences (Tilcsik, 2010). Under each scenario, decoupling is a cost-avoidance measure. It involves "misalignment between surface structures and actual activities" (Haack et al., 2012, p.819), so that "organizations abide only superficially by institutional 
pressure and adopt new structures without necessarily implementing the related practices" (Boxenbaum \& Jonsson, 2008, p.81). Observers perceive an institutionally consistent organizational frontage, while, internally, managers avoid the trade-off with efficiency, the complexities of institutional pluralism, or the challenge to personal utility that might otherwise result from full compliance. In practice, though, decoupling is often temporary, with the external-internal gap reducing over time. Explanations for this include (fear of) increased inspection (Cole, 2012), cognitive dissonance or guilt among employees prompting behavioral modifications (Fiss \& Zajac, 2006; Haack, et al., 2012), and a chain reaction whereby purely symbolic actions eventually bring more substantive compliance (Tilcsik, 2010).

Viewed from this institutional perspective, PSBs are not simply the outcome of rational bargaining between utility-maximizing actors. Bargains do not exist in a cultural vacuum, but must reflect wider normative standards if they are to be tolerated by external constituencies. This is partly recognized by Hood and Lodge (2006, p.6), who argue that PSBs "depend on the combined strategic choices of all the parties to the bargain," including "politicians, political parties, clients, and the public at large" (original emphasis). But given the potential independence of explicit and tacit deals, the institutional perspective adds to the theory of PSBs by describing a mechanism for handling conflict between rational and cultural imperatives. Depending on context, PSB legitimacy might be defined by senior politicians in the core executive, who have expectations of how junior ministers will behave toward their officials; central civil service authorities, who oversee the state bureaucracy; legislatures; the media; citizens; and transnational institutions. The costs of complying with these institutional pressures will depend upon bargaining actor preferences, but may include increased exposure to blame, new difficulties in transacting business, decreased power or influence, and greater information asymmetry. Finally, there is the question of whether PSB decoupling is persistent or transitory, and what promotes or undermines stability long term.

\section{RESEARCH DESIGN}

Having reasoned that the different characteristics of explicit and tacit PSBs mean that composite bargains involve more-or-less loosely coupled agreements, and that institutional decoupling is a specific type of looseness produced by rationalinstitutional conflict, the task remains of demonstrating this logic empirically. In the 
space available, only a partial illustration is possible. To observe loose coupling requires in-depth methods which preserve contextual details about organizations (Weick, 1976, p.10). Hence, breadth is traded for depth in the following case study, which concentrates on institutional explanations and examines only the loyalty/responsibility dimension of PSBs. Institutional decoupling is an extreme case of looseness for which recognized analytic frameworks are already available. And loyalty involves relatively intangible inducements and contributions concerning bureaucratic identity and autonomy, bringing particular opportunity for exploring the interrelation between explicit and tacit agreements.

The case study is an instance of the public-service decentralization 'agencification' - that became fashionable globally during the 1980s and 1990s (Smullen, 2010). More than simply redrawing organizational boundaries, this sought to reconfigure all three PSB dimensions of reward, competency and loyalty. Agency managers could have fixed-term, performance-dependent contracts; could be recruited from the private sector for their leadership and management skills; and could have operational independence from politicians, less anonymity than regular officials, and some personal liability for performance. In terms of PSB categories, therefore, agencification promotes the delegated agency-type bargain and executive kind of loyalty (Hood, 2001; Hood \& Lodge, 2006, ch.9).

The U.K.'s 'Next Steps' program of 1988-1997 was among the most comprehensive examples of agencification (Gains, 2003; James, 2003). Yet little is known about its long-term outcomes, including whether the changed bargain continues as intended today. Accordingly, the article draws on in-depth qualitative fieldwork undertaken in the Ministry of Justice and the central Cabinet Office during the 2010-2015 Conservative-Liberal Democrat Government. The justice sector at this time comprised three executive agencies, each of which originated under Next Steps. It thus affords opportunity for a longitudinal case study.

The explicit PSB in the justice sector was recorded from published documents and public statements, including policy literature and parliamentary hearings. A literature review and archival research captured the history of Next Steps and the justice sector. The tacit deal was registered from more than fifty interviews with middle-ranking and senior officials, as well as collation of unpublished documentation such as organization charts, meeting minutes and staff magazines. This fieldwork followed an ethnographic and interpretive logic of inquiry, seeking a 
contextualized, 'insider' perspective on organizational structures, management independence and political-administrative relations. This reflects the focus on loyalty/responsibility, as defined above. Interviews were conversational and only loosely structured around the research themes, in order to capture participants' worldviews and limit their preconditioning by the researcher (Schwartz-Shea \& Yanow, 2012). This helped register the taken-for-granted understandings that comprise tacit PSBs and are difficult to perceive externally. ${ }^{i i i}$

\section{AGENCIFICATION IN THE UNITED KINGDOM}

\section{Background: Agencies across government, 1988-2013}

Agencification was among several administrative reforms initiated by the Thatcher Government after 1979. The idea came in a report criticizing a lack of management competence among senior officials and the overburdening of ministers with both policy and delivery responsibilities (Efficiency Unit, 1988). As remedy, public services would be decentralized to semi-autonomous, task-specific agencies. Epitomizing executive-type loyalty and a delegated PSB, managers would no longer receive day-to-day instruction from ministers and policymakers, would have authority to direct their organizations toward pre-set performance targets, and would be accountable for doing so. Obligations and entitlements were enshrined in quasicontractual 'framework documents'.

Next Steps was soon recognized as "the most ambitious attempt at civil service reform in the twentieth century" (Treasury and Civil Service Committee, 1990, p.v). Over a decade, 138 agencies were created, employing some 60 per cent of the civil service (James, 2003). When the new Labour Government arrived in 1997, it saw merit in the program, but, given its wider 'joined-up government' agenda, was concerned to prevent agencies from becoming disconnected from departments and minsters (Gains, 2003). By 2010, the population had fallen to 84 organizations, although employment grew to 62 per cent, indicating that merges rather than deagencification predominated (Elston, 2013a). Thereafter, the Conservative-Liberal Democratic Coalition elected in 2010 oversaw large-scale de-agencification in social security and immigration, whilst also establishing new agencies in health, education

\footnotetext{
iii On the research methodology, see Elston (2013b).
} 
and justice. It still considered executive agencies the "default" model for public service delivery in central government (Cabinet Office, 2011).

Formally, then, Next Steps was successfully implemented and has withstood the test of time. Assuming a tightly coupled explicit-tacit PSB, the deal between politicians and operational managers would appear transformed. But what about informally? The delegation and contract-like control that epitomized the new political-administrative deal were initially reinforced by centralized reporting of agency performance, frequent ministerial announcements of agency targets, and the advent of direct correspondence between chief executives and MPs. However, central reporting discontinued after 1997 , and ministerial statements gradually lessened in frequency and significance. Moreover, some practices initially reserved for agencies transferred into core departments (Bezes \& Lodge, 2015), so that, altogether, agencies lost their "distinct and celebrated identity" (Gains, 2003, p.17).

Declining salience does not necessarily indicate a weakened PSB, and might simply reflect its normalization. But evidence also suggests a gradual deautonomization of agencies, undermining the intended switch from partnership to executive loyalty. Labour ministers often answered MPs' questions directly, rather than leaving this to chief executives (Interview-A); some framework documents grew obsolete, while others were re-written for entire departments, undermining the principal-agent contractualism; and many chief executives regained responsibility for advising ministers on policy, contrary to their original delivery focus (Elston, 2013a). Allen Schick (2002, pp.50-51) reports that, after 1997, agencies had "less autonomy than the initial design promised," and were reconceived as subdivisions of departments rather than independent entities (see also Gains, 2003). This was entrenched in 2010, when agencies were excluded from comprehensive government reforms of arm's-length 'quangos' because these were already tightly controlled by ministers (Flinders \& Skelcher, 2012). Moreover, a recent discourse analysis found that, without any formal redefinition of 'agency status', politicians and officials speak of agencies very differently today, emphasizing political control and accountability, rather than de-politicization and decentralization (Elston, 2014).

\section{Explicit PSBs in the justice sector}

The first justice agency was the Prison Service, devolved from the Home Office in 1993. The Public Trust Office and Court Service followed in the Lord 
Chancellor's Department in 1994 and 1995. Thereafter, the fragmented justice system underwent gradual rationalization. Local probation services and magistrate courts administration were brought into central government; administrative tribunals transferred from individual government departments into the justice portfolio; political and judicial roles at the top of the judiciary were separated, ending a centuries-old anachronism; and the Ministry of Justice (MoJ) was created in 2007 by merging parts of the Home Office and the Department for Constitutional Affairs, which itself had replaced the Lord Chancellor's Department in 2003. All the while, agencies remained at the heart of the justice sector. Prisons underwent successive restructurings, merging with probation in 2008 to form the current National Offender Management Service (NOMS). The Court Service combined with the magistrates courts in 2003, before merging with the Tribunals Service in 2011 to form HM Courts and Tribunals Service (HMCTS). And the Public Trust Office became the Office of the Public Guardian (OPG) in 2007. Figure 2 summarizes this complex genealogy.

Figure 2: Agencies in the justice sector, 1993-2013

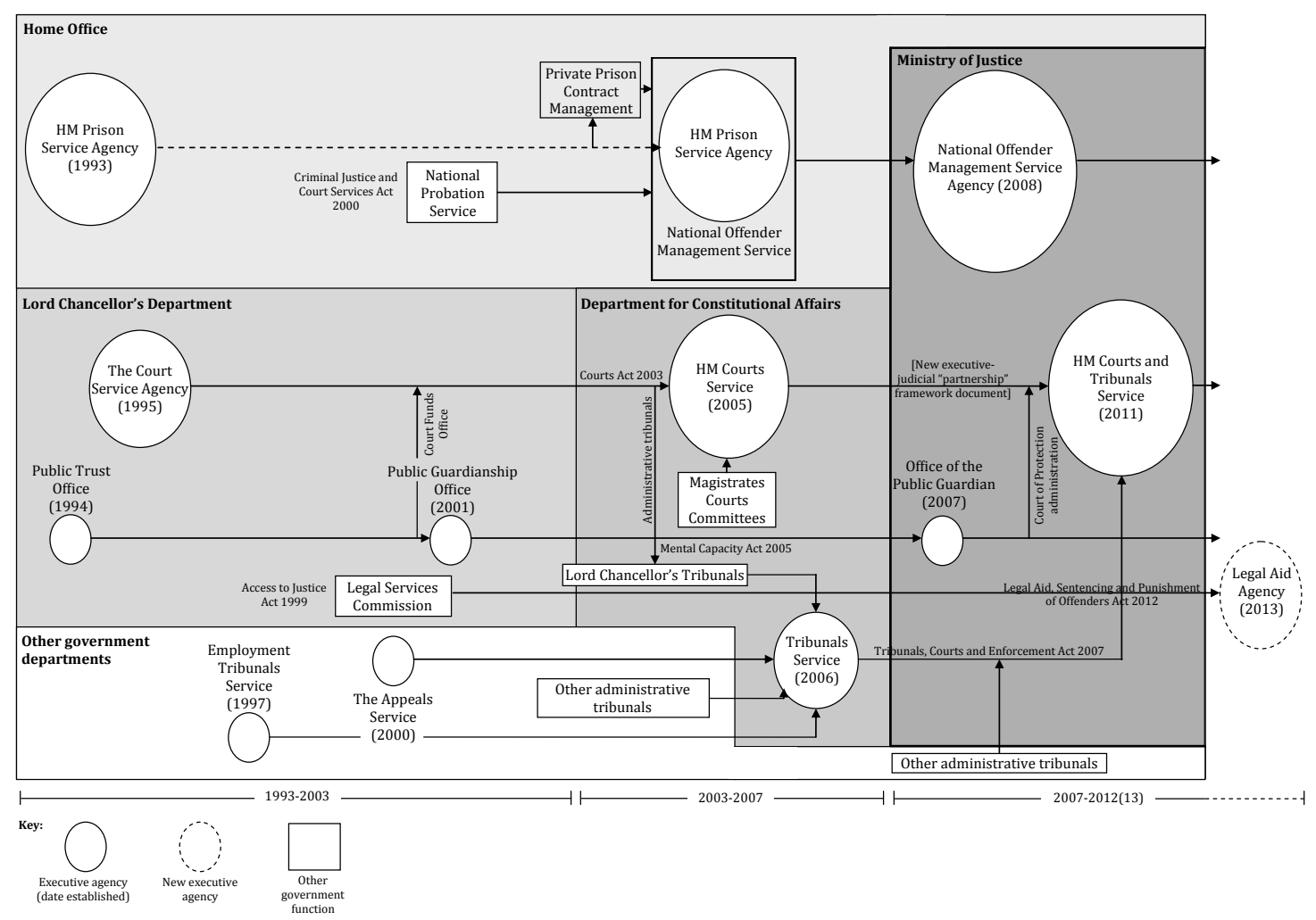

Formally, then, not only have the justice agencies withstood many wider reforms, but their use has increased since Next Steps, first with the addition of 
magistrates courts, probation services and tribunal administration, and more recently by reclassifying the Legal Services Commission as a fourth agency. Agencies are more multipurpose than originally; but they maintain many traits indicative of a delegated PSB and executive loyalty, including separate corporate governance structures, management boards, audit committees and non-executive directors. Senior management are named publicly. Individual accounts and business plans are presented annually to parliament, and individual framework documents are regularly updated, defining responsibilities, the frequency of chief executive meetings with ministers and the conditions for reviewing and/or terminating the agreement. These routines all portray political-administrative relations closely resembling the original Next Steps deal.

\section{Tacit PSBs in the justice sector}

The Prison Service emerged at a time when overcrowding, rioting and escapes were endemic. An external report warned of continued failure should the Home Office not "take its hands off" the Service and "separate Ministers from day-to-day involvement" (Lygo, 1991, p.11). When the Home Secretary established the agency, he similarly described the "autonomy" and "freedom" it brought (HM Prison Service, 1993, p.2). Indeed, so extensive was the intended executive-style delegation that doubts emerged over the continuing need for a junior minister responsible for prisons (Lewis, 1997, p.14). However, politicians retained significant involvement, as was revealed when the first chief executive (who was recruited from the private sector) was dismissed for poor performance, only to plead unwarranted ministerial interference and receive sizable compensation. Once in office, the Labour Government took more overt control and resumed parliamentary responsibility for reporting on prisons. By the mid-2000s, it proposed full de-agencification, claiming the Service had been an agency "in name only" (Home Office, 2004, p.15). Although there was a quiet reprieve, the then chief executive later recalled, "the autonomy, the ability ... to get on and manage the organization, has been significantly eroded... I was spending 70 per cent of my time ... managing Ministers" (radio interview). Thus, irrespective of the continued agency classification, political-administrative relations resumed their traditional, 'partnership' form after the turbulence of the mid1990s. 
This frontstage-backstage disconnect in loyalty/responsibility continues today in NOMS - the larger descendent of the prison service. One interviewee suggested that it still holds agency status "in theory," but in practice, "pretending that it's at arm's-length from ministers is just pretending" (Interview-B). Another remarked: “Agencies, I always thought, were quite arm's length, ... but as long as I've been here, it never has been" (Interview-C). This was often explained by political salience. Criminal justice is notoriously a "media-interested bit of the world" (Interview-D), and "when things go wrong in our bit of the world, it is the end of the world" (Interview-E). Consequently, "Ministers just cannot comfortably sit at an arm's length" (Interview-B), and are involved extensively in both high-level and detailed decisions (Interview-D). One project manager described how "The minister has been very keen to engage with me directly" (Interview-E), and another recalled the "formal" ministerial meetings and "informal" conversations scheduled in their diary the following week (Interview-F). Consequently, there is little to distinguish NOMS from the main department, as this account of ministerial briefings indicates:

"Effectively, we ... show up as MoJ officials, and we're all part of the Ministry, so we're doing 'MoJ-officials-advising-our-ministers' jobs. The fact that, of course, when we walk away we wear slightly different badges and ... do a different bit of the system- It's much more just like: 'The officials from the department are coming to just brief the minister,' which is probably the way it should be." (Interview-B)

Turning next to the Court Service, this agency emerged two years after prisons but was heralded with the same rhetoric of delegation and de-politicization. Following the tenor of executive-type loyalty, a quasi-contractual arrangement was anticipated, as the agency's financial memorandum reveals:

"All references to the Department should be read as meaning officials acting on behalf of the Lord Chancellor or Permanent Secretary.... References to the Court Service should be read as meaning officials acting on behalf of the Chief Executive."

This emulation of commercial language firmly separates minister and chief executive as independent, contracting parties, and invests considerable authority in the latter, whose officials will negotiate (rather than simply accept) the agency's budget allocation. Subsequently, however, the Court Service experienced mergers and reintegration similar to prisons. The agency and department are today "much more integrated than we've ever been before" (Interview-G), with the chief executive being "an absolute, equitable member of the [MoJ] senior management team" - a position "at odds" with the original Next Steps intention (Interview-H). Indeed, HMCTS staff sit on many subcommittees of the main MoJ management board (Interview-A, -G), 
and "spend as much ... time worrying about NOMS's financial issues" as they do about HMCTS's (Interview-H).

Nonetheless, a constraint on this departmental re-integration was HMCTS's position at the intersection of the executive and judicial branches of government. As cabinet minister, head of the judiciary and speaker of the House of Lords, the ancient office of Lord Chancellor was long seen as constitutionally dubious (Woodhouse, 2001). In 2003, the intention to remove the legislative and judicial functions was announced as part of a cabinet reshuffle "in an almost whimsical, accidental way" (Interview-G). The Lord Chief Justice became head of the judiciary, and the Lord Chancellor just an ordinary cabinet minister. But judges were concerned at their lost representation in cabinet. Thereafter, in 2007, the further announcement to bring together courts and prisons within the new $\mathrm{MoJ}$ caused even greater acrimony. The judiciary feared that the two agencies would vie over a single budget, and the inexorably rising prison population force underfunding in the courts. As resolution, HM Courts Service became a 'partnership' between the Lord Chancellor (minister) and Lord Chief Justice (senior judge). Judges sat on the agency board, and all agency staff gained a joint loyalty to the judiciary alongside ministers.

This had a profound effect on the interpretation of agency status. While the original logic of managerial independence was recognized as the 'theory' but not the practice in NOMS, it was superseded entirely in HMCTS by a concern to demarcate this constitutionally-dubious partnership from the rest of the Ministry. One official had "forgotten" that an agency framework document pre-existed judicial involvement in the agency, and then dismissed it as "relatively inconsequential" (Interview-I). Another recalled how, in meetings, judges would cite intricate details of the framework: "[they] would raise Paragraph-6.1.1a. subsection-2." Asked whether ministers behaved similarly, the reply was:

"Oh good grief, no. No, no, no. I don't think the framework document was ever there for the department. I think the framework document was there for the relationship with the judiciary, to put us on this footing." (Interview-J)

This consternation at the suggestion of quasi-contractual relations with ministers illustrates the disconnect between the frontstage and backstage view of HMCTS, and the distance travelled since the court service was first agencificed in 1995. As a third official confirmed, today it is the judicial partnership - not agency status - that conditions bureaucratic relations with ministers: 
"[The partnership is] actually quite a weird thing... I've personally found it quite difficult... Because, on this white paper, which is a political document (obviously, by its very nature): I'm a civil servant and so I will write whatever the minister wants me to write, because that's how we operate. And then I'm also responsible to the Lord Chief [Justice], who won't want him saying that. So I've been in a few meetings where I've said: 'With my partnership hat on, looking at the Lord Chief, we can't write that; however, of course, with my civil-service hat on, I know why you want to'." (Interview-K)

The implication is that, contrary to the external image of executive-type loyalty, the civil servant's bargain with ministers is unaffected by agency status: like any other bureaucrat, you should write "whatever the minister wants ... because that's how we [- the civil service - ] operate." Yet, for HMCTS, the additional loyalty to judges complicates the bargain.

Finally, the third justice agency, OPG, is responsible for safeguarding the legal affairs of adults with mental incapacity. Smaller than NOMS and HMCTS, its autonomy has similarly diminished since Next Steps (Interview-L). The agency classification was now regarded with some apathy, one interviewee claiming that it made "no difference whatsoever" (Interview-M) and another simply identifying an accountability and corporate governance function:

"The key principle is: executive agencies - they are part of the parent department, even if the construction creates some other boundaries and accountability, not least in terms of defined accounts, the Accounting Officer responsibility for those resources, being able to account for that and for the delivery to Parliament..." (Interview-L)

This interpretation recurred elsewhere (Interview-G, -M, -N). An official in NOMS identified "some devolved operational accountability" in the chief executive's financial responsibilities (Interview-B). And an MoJ official, asked why agency status persisted in MoJ, remarked (somewhat equivocally):

"You have a more formal board governance structure with [non-executive directors], which ... adds another level of scrutiny. I guess I would [also] probably say, because their budgets are so big, having [agencies] report their own accounts is useful. And ... having Agency Accounting Officers accountable for the large chunks of money means that there's more direct accountability." (Interview-O)

Notably, these descriptions make no reference to the Next Steps idea of authority being devolved from ministers to senior officials - only to their delegated accountability.

\section{DISCUSSION}

Loyalty and responsibility in the British civil service has traditionally been of the 'partnership' variety, where "public servants work together with elected politicians but have no separate identity either in directing public organizations or in 
determining policy" (Hood \& Lodge, 2006, p.116). Next Steps aimed at disrupting that bargain, providing officials with some independence by creating semiautonomous organizations, designating civil service leaders as chief executives, and enshrining their freedoms and obligations in quasi-contracts. Political steering would come through policy design and target-setting, and bureaucratic accountability through performance monitoring by sponsorship teams in departments.

Ostensibly, much of Whitehall attained this new, executive-type bargain, and continues to sustain it today. Many agencies remain and new ones continue to appear. Agency documentation continues to be published, albeit with less fanfare than hitherto; chief executives are still named publicly; and, on financial matters, they account to parliament directly, independent of ministers. Nevertheless, this image the explicit or 'frontstage' PSB - is misleading, certainty in the justice sector, and possibly more widely. From committee structures to financial planning, the justice sector is far more integrated than Next Steps originally intended and than appears to the outside world today. Framework documents remain in place; but, in practice, departmental oversight is far more hierarchical than contract-based. Indeed, the MoJ disbanded its sponsorship team for the largest justice agencies in 2010 after a review found this to be a duplicative activity that simply involved "managing ourselves" (unpublished document). Moreover, not only are ministerial liaisons a daily occurrence for agency staff, but they are broadly accepted as "the way it should be" (Interview-B). Thus, whereas existing PSB theory would interpret such interference in formally delegated matters as 'cheating' by politicians (Hood \& Lodge, 2006, pp.164-166), the story here is more complex. The PSB that is visible to outside observers and that might spark allegations of cheating is in fact superficial and an incomplete representation of how politicians and bureaucrats have agreed (if under duress) to act toward one another. In other words, the explicit and tacit PSB are only loosely coupled to one another, as officials intimated when describing the "theory" and "pretence" of NOMS's agency classification, how the modern HMCTS was "at odds" with its agency label, and how OPG's classification made "no difference".

There are both institutional and non-institutional reasons for loose coupling in organizations (Bromley \& Powell, 2012). On the one hand, the different life cycles of explicit and tacit PSBs might explain the inconsistencies observed above, with continuing formal agencification simply a relic of past reforms. Certainly, while it remains unclear that executive-type loyalty was ever fully implemented in the 1990s, 
interviews suggest that the gap between the formal and informal deal widened considerably after 1997. Nonetheless, there were also strong regulatory and cultural prescriptions for how politicians and civil servants should act toward one another, indicating that the various institutional explanations of decoupling might apply too.

During the 1979-1997 Conservative Government, the core executive determined that officials required more freedom and personal accountability if public services were to improve, albeit with some hesitation from the Treasury (Elston, forthcoming). Similarly, agencification was welcomed in parliament, though with concern for preserving ministerial accountability and ensuring that policymaking remained grounded in operational realities (Treasury and Civil Service Committee, 1990). And agencification was also widely promoted in the international 'goodgovernance' community, including by the OECD. Yet, in all three domains, support for the delegated PSB proved transient. As Amanda Smullen (2010, pp.38-39) explains, once internationally regarded as "an all-purpose solution to public management problems," agencies came to be viewed as major "problems for accountability and coordination." In the UK, the Labour Government duly sought deautonomization and increased coordination after 1997 (Schick, 2002; Gains, 2003), before, latterly, the Coalition Government made enhancing ministerial control over, and accountability for, public services once of its central objectives, with strong support from parliament (Flinders \& Skelcher, 2012; Elston, 2014).

Institutional theory predicts that these cultural imperatives will lead to decoupling if organizational compliance incurs excessive costs, whether by reducing internal efficiency (Meyer \& Rowan, 1977), creating inconsistency and complexity (Brunsson, 2002), or diminishing personal utility for leaders (Westphal \& Zajac, 2001; Tilcsik, 2010). The data above provides some support for all three explanations, although most strongly for the first and third. Thus, reading 'efficiency' as the ease of conducting the business of government efficiently and democratically, while some interviewees approved of the independence that agencification had initially brought, many also described its pathologies. From increasing organizational overheads and making employers compete with one another to attract staff (Interview$\mathrm{G},-\mathrm{H})$, to requiring ministers to disengage from matters for which, regardless of the agency classification, parliament and the public would inevitably hold them responsible (Interview-A, -B), these costs provide politicians and bureaucrats alike 
with incentives for limiting their actual move toward a delegated PSB and executivetype loyalty.

Secondly, in terms of institutional pluralism, the main imperatives for legitimate political-administrative relations actually appeared sequentially as changing fashions, rather than concurrently as heterogeneous environments. This is reflected in the evolving rationale for agencification, from the initial focus on depoliticization and decentralization (epitomized by uncertainty about the continuing need for a junior prisons minister after agencification), to the recent emphasis on corporate governance, accountability and control. However, at a more tangible level, there was some heterogeneity; for example, in the Treasury's initial resistance to Next Steps, in Parliament's concern for ministerial accountability, and in recent pressures from the judiciary over independence and court funding. Balancing these different priorities might have contributed to the explicit-tacit decoupling.

Thirdly, focusing on credit-claiming and blame-deflection as basic preferences for the leaders of political bureaucracies (Hood, 2011), the case study also supports the theory that decoupling can protect the interests of organizational elites. Politicians face a trade-off when agreeing the loyalty/responsibility dimension of PSBs. Too much delegation, and they won't be credited with policy successes; too little, and they risk being blamed for administrative mistakes (Hood, 2011). By decoupling the explicit and tacit PSB, and contriving a different frontsage and backstage, politicians delay their decision about whether to pursue a credit-claiming (centralized) or blameavoiding (delegated) strategy until the circumstances are better understood. This was partly seen in the politically-salient NOMS, where an official described how the agency's framework document was only invoked "if we're in difficulty":

"That was when we lost a Category A prisoner... There were some questions [in parliament], and, obviously, someone's gonna try and pin something on [the Secretary of State] about his level of responsibility." (Interview-P)

Although unreflective of NOMS's integration into the MoJ hierarchy, referencing the framework document created distance between minister and agency, and thus deflected blame during the crisis. Similarly, speaking of the Home Office, whose UK Border Agency was then in serious difficulties, the same official speculated:

\footnotetext{
"I suspect the ministers, both the Immigration Minister and the Home Secretary, have read their agency framework to see what their protection is if it cocks up ... and I suspect the directors of UKBA are reading theirs to say, 'What are we accountable for?'” (Interview-P)
}

Thereafter, faced with an escalating crisis, the Home Office eventually reintegrated this agency into the core department. But a leaked memo from the permanent 
secretary reassured staff that "most of us will still be doing the same job in the same place with the same colleagues for the same boss" (BBC, 2013). This provides further evidence of how frontstage-backstage decoupling can serve blamemanagement purposes, in line with the interest-based account of institutional decoupling

\section{CONCLUSION}

Using insights from organizational sociology and new data on the longevity of a high-profile administrative reform in the UK, this article has explored the explicittacit duality that is widely ascribed to public service bargains. Having shown that differences between these two types of deal mean that PSBs can operate as loosely coupled arrangements, and that institutional theory helps to explain a particular type of incongruence derived from rational-institutional conflict, there are perhaps three primary implications for mainstream PSB research.

Firstly, just as Hood and Lodge (2006, ch.7) find some combinations of reward, competency and loyalty more compatible than others, the same is likely of explicit and tacit deals. Excessive difference is more easily detected and ridiculed by outside constituencies. Hence, in the case above, it was two variants of the same PSB category - the delegated- and directed subtypes of the agency bargain - that appeared simultaneously at the frontstage and backstage. Therefore, further research should not only determine the extent of loose coupling in different circumstances, but also what constrains or enables this, and whether certain types of bargain are especially prone to inconsistencies. Secondly, given that Hood and Lodge (2006, pp.199-201) foresee a future of growing complexity in PSBs, an important question to ask is whether loose coupling is responsible for, or a reaction to, increasing convolution. Operating with different rules in public and in private certainly brings added complexity; and yet, if institutional pressures demand more intricate PSBs, decoupling might actually buffer internal relations from over-complication. Thirdly, loose coupling affects how bargains evolve. Reducing interdependencies within organizations slows down and/or dilutes externally-driven change (Glassman, 1973; Weick, 1976), meaning that some forms of PSB might be inherently change resistant. Moreover, since politicians generally have more public voice than bureaucrats, and thus greater influence over the frontstage PSB that informs external impressions of actor behaviour, decoupling highlights new power asymmetries between bargain participants. Future research 
might consider when and how this strategic advantage is deployed, and what its consequences are for the breakdown of PSBs by cheating.

Alongside these additions to the original PSB agenda, research should be expanded to consider more fully how institutional pressures combine with utilitymaximising behaviour to produce bargain outcomes. What are the main sources of PSB legitimacy? What are the costs and compromises of institutional compliance, and how can participants influence societal perceptions of legitimacy in order to preempt these costs, maximize preferences and avoid the need for decoupling?

Moreover, where rational and institutional imperatives do conflict, how can actors achieve the "low behavioral visibility" (Wijen, 2014, p.308) necessary to sustain an inconsistent frontstage and backstage over the longer term? Here, one interesting question is whether the external constituencies who define legitimacy might also be complicit in the decoupling by limiting their scrutiny of the deal and thus their opportunity to uncover the deception (Meyer \& Rowan, 1977, p.359).

Finally, lessons for would-be reformers are twofold. Firstly, formalization of civil service roles and responsibilities in statues or quasi-contracts does not end ambiguity entirely. Indeed, if inducements and contributions are open to multiple interpretations, or if implicit understandings evolve out-of-sync with formal contracts, ambiguity might actually increase under formalization. Caution is thus needed to build systems of accountability that can adjudicate the tacit as well as the explicit elements of PSBs, and detect strategic misuse of formalization by those in positions of power. Secondly, as the major administrative reforms initiated around the world during the 1980s and 1990s enter their second, third and fourth decades, it is necessary to evaluate whether their residual architecture continues to be used as intended, or whether those legacies are being somehow manipulated. The Next Steps program is a case in point. Originally aimed at matching managerial authority with a measure of personal accountability, the result some 25 years later is a series of organizations that, superficially, look very much as originally intended, and yet operate quite differently in practice. This risks responsibility for policy mistakes being misdirected, and agencification becoming principally about blame-deflection rather than public service improvement. 


\section{BIBLIOGRAPHY}

Aberbach, J.D., Putnam, R.D., \& Rockman, B.A. (1981). Bureaucrats and Politicians in Western Democracies. Cambridge, Mass.: Harvard University Press.

Aucoin, P. (2012). New Political Governance in Westminster Systems: Impartial Public Administration and Management Performance at Risk. Governance, 25(2), 177-199.

Barnard, C. (1938). The Functions of the Executive. Cambridge, Mass.: Harvard University Press.

BBC. (2013). UK Border Agency 'Not Good Enough' and Being Scrapped. Downloaded from: http://www.bbc.co.uk/news/uk-politics-21941395

Bezes, P., \& Lodge, M. (2015). Civil Service Reforms, Public Service Bargains and Dynamics of Institutional Change. In F. Van der Meer, J.C.N. Raadschelders \& T.A.J. Toonen (eds.), Comparative Civil Service Systems in the 21st Century (pp. 136-161). Basingstoke: Palgrave Macmillian.

Bourgault, J., \& Van Dorpe, K. (2013). Managerial Reforms, Public Service Bargains and Top Civil Servant Identity. International Review of Administrative Sciences, 79(1), 49-70.

Boxenbaum, E., \& Jonsson, S. (2008). Isomorphism, Diffusion and Decoupling. In R. Greenwood, C. Oliver, R. Suddaby \& K. Sahlin (eds.), Sage Handbook of Organizational Institutionalism (pp. 78-98). Thousand Oaks: Sage.

Bromley, P., \& Powell, W.W. (2012). From Smoke and Mirrors to Walking the Talk: Decoupling in the Contemporary World. Academy of Management Annals, 6(1), 483-530.

Brunsson, N. (2002). The Organization of Hypocrisy. Oslo: Abstrakt.

Burns, J.P., Wei, L., \& Peters, B.G. (2013). Changing Governance Structures and the Evolution of Public Service Bargains in Hong Kong. International Review of Administrative Sciences, 79(1), 131-148.

Cabinet Office. (2011). Government Response to the Public Administration Select Committee Report, "Smaller Government: Shrinking the Quango State". (Cm 8044). London: The Stationery Office.

Cohen, M.D., March, J.G., \& Olsen, J.P. (1976). People, Problems, Solutions and the Ambiguity of Relevance. In J.G. March \& J.P. Olsen (eds.), Ambiguity and Choice in Organizations (pp. 2437). Bergen: Universitetsforlaget.

Cole, W.M. (2012). Human Rights as Myth and Ceremony? Reevaluating the Effectiveness of Human Rights Treaties, 1981-2007. American Journal of Sociology, 117(4), 1131-1171.

Efficiency Unit. (1988). Improving Management in Government: The Next Steps. London: The Stationery Office.

Elston, T. (2013a). Developments in UK Executive Agencies: Re-examining the 'DisaggregationReaggregation' Thesis. Public Policy and Administration, 28(1), 66-89. . (2013b). Reinterpreting Agencies in UK Central Government: On Meaning, Motive and Policymaking. PhD thesis, University of Nottingham.

. (2014). Not So 'Arm's Length': Reinterpreting Agencies in UK Central Government. Public Administration, 92(2), 458-476.

. (forthcoming). Principles Meet Practicalities: Challenges of Accountability Reform in the British Civil Service. In T. Christensen \& P. Lægreid (eds.), The Ashgate Research Companion to Accountability and Welfare State Reforms: Ashgate. 
Emerson, R.M. (1962). Power-Dependence Relations. American Sociological Review, 27(1), 31-41.

Fiss, P.C., \& Zajac, E.J. (2006). The Symbolic Management of Strategic Change: Sensegiving via Framing and Decoupling. Academy of Management Journal, 49(6), 1173-1193.

Flinders, M., \& Skelcher, C. (2012). Shrinking the Quango State: Five Challenges in Reforming Quangos. Public Money \& Management, 32(5), 327-334.

Gains, F. (2003). Surveying the Landscape of Modernisation: Executive Agencies under New Labour. Public Policy and Administration, 18(2), 4-20.

Glassman, R.B. (1973). Persistence and Loose Coupling in Living Systems. Behavioral Science, 18(2), 83-98.

Goffman, E. (1956). The Presentation of Self in Everday Life. Edinburgh: University of Edinburgh.

Grube, D. (2015). Responsibility to Be Enthusiastic? Public Servants and the Public Face of 'Promiscuous Partisanship'. Governance, 28(3), 305-320.

Haack, P., Schoeneborn, D., \& Wickert, C. (2012). Talking the Talk, Moral Entrapment, Creeping Commitment? Exploring Narrative Dynamics in Corporate Responsibility Standardization. Organization Studies, 33(5-6), 815-845.

HM Prison Service. (1993). Framework Document. London.

Home Office. (2004). Reducing Crime - Changing Lives. London.

Hondeghem, A., \& Van Dorpe, K. (2013). Performance Management Systems for Senior Civil Servants: How Strong is the Managerial Public Service Bargain? International Review of Administrative Sciences, 79(1), 9-27.

Hood, C. (2001). Public Service Bargains and Public Service Reform. In B.G. Peters \& J. Pierre (eds.), Politicians, Bureaucrats and Administrative Reform (pp. 13-21). London: Routledge.

. (2002). Control, Bargains, and Cheating: The Politics of Public-Service Reform. Journal of Public Administration Research and Theory, 12(3), 309-332.

. (2011). The Blame Game. Oxford: Princeton University Press.

Hood, C., \& Lodge, M. (2006). The Politics of Public Service Bargains. Oxford: Oxford University Press.

Interview-A, senior civil servant

Interview-B, senior civil servant

Interview-C, senior civil servant

Interview-D, senior civil servant

Interview-E, civil servant

Interview-F, civil servant

Interview-G, senior civil servant

Interview-H, senior civil servant

Interview-I, civil servant 
Interview-J, civil servant

Interview-K, senior civil servant

Interview-L, civil servant

Interview-M, civil servant

Interview-N, civil servant

Interview-O, civil servant

Interview-P, civil servant

James, O. (2003). The Executive Agency Revolution in Whitehall. Basingstoke: Palgrave Macmillan.

Lægreid, P. (2000). Top Civil Servants Under Contract. Public Administration, 78(4), 879-896.

Lewis, D. (1997). Hidden Agendas: Politics, Law and Disorder. London: Hamish Hamilton.

Lodge, M. (2010). Public Service Bargains in British Central Government: Multiplication, Diversification and Reassertion? In M. Painter \& B.G. Peters (eds.), Tradition and Public Administration (pp. 99-113). Basingstoke: Palgrave Macmillan.

Low, S. (1904). The Governance of England. London: T. Fisher Unwin.

Lygo, R. (1991). Management of the Prison Service. London: Home Office.

March, J.G., \& Simon, H.A. (1993). Organizations (2nd ed.). Cambridge, Mass.: Blackwell.

Meyer, J.W., \& Rowan, B. (1977). Institutionalized Organizations: Formal Structure as Myth and Ceremony. American Journal of Sociology, 83(2), 340-363.

Orton, J.D., \& Weick, K.E. (1990). Loosely Coupled Systems: A Reconceptualization. Academy of Management Review, 15(2), 203-223.

Perry, J.L., Engbers, T.A., \& Jun, S.Y. (2009). Back to the Future? Performance-Related Pay, Empirical Research, and the Perils of Persistence. Public Administration Review, 69(1), 39-51.

Polanyi, M. (1958). Personal Knowledge. London: Routledge \& Kegan Paul.

Salomonsen, H.H., \& Knudsen, T. (2011). Changes in Public Service Bargains: Ministers and Civil Servants in Denmark. Public Administration, 89(3), 1015-1035.

Schaffer, B. (1973). The Administrative Factor. London: Cass.

Schelling, T.C. (1956). An Essay on Bargaining. American Economic Review, 46(3), 281-306.

Schick, A. (2002). Agencies in Search of Principles. In Organisation for Economic Co-Operation and Development (OECD), Distributed Public Governance: Agencies, Authorities and Other Government Bodies (pp. 33-52). Paris.

Schwartz-Shea, P., \& Yanow, D. (2012). Interpretive Research Design. New York: Routledge.

Scott, W.R. (1995). Institutions and Organizations. Thousand Oaks: Sage.

Smullen, A. (2010). Translating Agency Reform. Basingstoke: Palgrave Macmillan. 
Steen, T., \& Van der Meer, F. (2011). Public Service Bargains in Dutch Top Civil Service. Public Policy and Administration, 26(2), 209-232.

Tilcsik, A. (2010). From Ritual to Reality: Demography, Ideology, and Decoupling in a PostCommunist Government Agency. Academy of Management Journal, 53(6), 1474-1498.

Treasury and Civil Service Committee. (1990). Progress in the Next Steps Initiative. (HC 481). London: The Stationery Office.

Van der Meer, F.M., Van den Berg, C.F., \& Dijkstra, G.S. (2013). Rethinking the 'Public Service Bargain': The Changing (Legal) Position of Civil Servants in Europe. International Review of Administrative Sciences, 79(1), 91-109.

Weick, K.E. (1976). Educational Organizations as Loosely Coupled Systems. Administrative Science Quarterly, 21(1), 1-19.

Westphal, J.D., \& Zajac, E.J. (2001). Decoupling Policy from Practice: The Case of Stock Repurchase Programs. Administrative Science Quarterly, 46(2), 202-228.

Wijen, F. (2014). Means versus Ends in Opaque Institutional Fields: Trading off Compliance and Achievement in Sustainability Standard Adoption. Academy of Management Review, 39(3), 302323.

Woodhouse, D. (2001). The Office of Lord Chancellor. Oxford: Hart.

\section{ACKNOWLEDGEMENTS}

The fieldwork was funded by a PhD studentship from the University of Nottingham. Previous versions of the article were presented at the 2015 Structure and Organization of Government (SOG) conference in Bergen, and at the 2015 Walking Away from Westminster? workshop in Oxford. Thanks go to Julia Fleischer, Martin Lodge, Dennis Grube and the two anonymous referees for their helpful comments. 